\title{
ARTIGOS
}

\section{FULMINANT HEPATTTIS WITH MICROVESICULAR STEATOSIS (A HISTOLOGIC COMPARISON OF CASES OCCURRING IN BRAZIL - LABREA HEPATITIS - AND IN CENTRAL AFRICA - BANGUI HEPATITIS)}

\section{Zilton A. Andrade, Jean L. Leshordes, Paul Ravisse, Raimundo Paraná, Aluizio Prata, João S. Barberino and Christian Trepo}

\begin{abstract}
A similar histopathologic picture of fatal hepatitis associated with widespread acute fatty changes in hepatocytes and single-cell necrosis was seen in epidemic cases occurring in two distinct equatorial areas having high prevalences of $H B V$ and $H D V$ infections. The cases were previously considered to be two different entities; Labrea hepatitis in Brazil, and Bangui hepatitis in the Central African Repubiic. However, the histopathologic findings suggest that they are pathogenetically and etiologically related to $H B V$ and HDV infections, probably modified by some as yet unknown factor(s) present in equatorial forest zones.
\end{abstract}

Key-words: Labrea hepatitis. Bangui hepatitis. Delta infection. Spongiocytic hepatitis.

A peculiar, highly fatal form of hepatitis, affecting primarily children and young adults, and occurring in microepidemics had been described in the Amazonian region of Brazil as Labrea fever $^{3} 491012$, in Colombia as Santa Marta fever ${ }^{7426}$ and in the French Guyana as Amazonian Black Fever ${ }^{22}$. More recently it has also been observed in Yucpa Indians in Venezuela ${ }^{1524}$ and linked to infection hepatitis Delta virus (HDV).

The clinico-pathological picture is that of an acute hepatitis with spotty coagulative and lytic cell necrosis and acute fatty change, with swollen, multivacuolated hepatocytes, which has been called "morular" or "spongiocytic" cells 3491012.

Geographically these cases have been reported from Equatorial areas of South America, areas which also have high prevalences for hepatitis B and hepatitis Delta virus carrier state. Epidemiological findings ${ }^{8}$, along with the demonstration of $\mathrm{HBsAg}, \mathrm{HBcAg}$ and Delta antigen in the liver cells, sometimes with the presence of Delta antigen within the nuclei of morular hepatocytes ${ }^{13}$ have strongly supported the

Gonçalo Moniz Research Center/FiOCRUZ; Federal University of Bahia (UFBA), Salvador, BA and University of Brasília (UnB), Brasília, Brazil; PB 6 bis, Tananarive, Madagascar; Institut Pasteur, Paris and Hepatitis INSERM Unit 69372, Lyon, France.

Address to: Dr. Zilion de Andrade. Centro de Pesquisa Gonçalo Moniz. R. Valdemar Faícão 121, 41295-001 Salvador, BA, Brasil.

Recebido para publicação em 12/03/92. assumption that HDV was the etiological agent of this peculiar type of hepatitis. However, there has been some reluctance in accepting such an etiology since the association of HBV and hepatitis Delta virus infection in other parts of the world ${ }^{17}$ neither reproduce the peculiar clinical features (microepidemics, psychicagitation and black bloody vomits), nor the characteristic histopathological hepatic changes seen in the cases from the Amazonian regions, except for an occasional isolated case ${ }^{18}$.

Recently, examples of fatal hepatitis with diffuse acute fatty changes in hepatocytes have been described as spongiocytic hepatitis in the region of Bangui in Central Africa ${ }^{20}$, which is also an equatorial forest area with high prevalence of $\mathrm{HBV}$ and hepatitis Delta virus infections.

Comparative studies between the cases which occur in those two regions seem important to further clarify the possible common etiology of these peculiar forms of hepatitis. Therefore, the present investigation consists of a comparative histological study of cases of Labrea hepatitis seen in Brazil and similar cases observed by one of us (JLL) in Bangui, capital of the Central African Republic.

\section{MATERIAL AND METHODS}

Labrea hepatitis cases. Table 1 summarizes the main clinical findings. Eight of the nine cases shown here have been previously reported ${ }^{13}$. Seven cases 
Andrade $Z A$, Lesbordes $J L$, Ravisse $P$, Paraná $R$, Prata A, Barberino JS, Trepo C. Fulminant hepatitis with microvesicular steatosis (A histologic comparison of cases occurring in Brazil - Labrea hepatitis - and in Central Africa - Bangui hepatitis). Revista da Sociedade Brasileira de Medicina Tropical 25:155-160, jul-set, 1992.

were from Labrea, a small village in the northwest part of the Amazonas state in Brazil, near the Bolivian border; one other came from Porto Velho, Rondonia, an area in the southwest Amazonian region and another was from Salvador, $\mathrm{Bahia}^{1}$, a large port city on the Brazilian eastern coast.

Bangui hepatitis. Seven unpublished cases were selected as representative of the epidemic. Criteria included presence of clinical data compatible with acute fulminant hepatitis and the finding of spongiocytic hepatocytes at histology. The main clinical findings are shown in Table 2. Serological

Table 1 - General data from nine cases of Labrea hepatitis.

Nr Sex $\begin{array}{r}\text { Age } \\ \text { (yrs) }\end{array} \begin{gathered}\text { Duration HDAg Hbsag Hbcag } \\ \text { (days) }\end{gathered}$

\begin{tabular}{lcccccc}
\hline$*$ & $\mathrm{~F}$ & 11 & 1 & + & + & - \\
$2 *$ & $\mathrm{M}$ & 11 & 3 & - & + & - \\
$3 *$ & $\mathrm{M}$ & 4 & 6 & + & + & - \\
$4 *$ & $\mathrm{M}$ & 16 & 7 & - & - & - \\
$5 *$ & $\mathrm{~F}$ & 9 & 4 & + & + & + \\
$6 *$ & $\mathrm{M}$ & 2 & 3 & + & + & + \\
$7 *$ & $\mathrm{M}$ & 9 & 4 & - & + & - \\
$8 *$ & $\mathrm{M}$ & 4 & 7 & - & - & - \\
9 & $\mathrm{~F}$ & 8 & $?$ & - & - & - \\
\hline
\end{tabular}

* Cases previously published.

Table 2 - General data from seven cases of fulminant Bangui hepatitis.

\begin{tabular}{lcccccc}
\hline $\mathrm{Nr}$ & Sex & $\begin{array}{c}\text { Age } \\
\text { (yrs) }\end{array}$ & $\begin{array}{c}\text { Duration } \\
\text { (days) }\end{array}$ & & HDAg Hbsag & Hbcag \\
\hline $1 *$ & $\mathrm{M}$ & 17 & 1 & + & + & + \\
$2^{*}$ & $\mathrm{~F}$ & 18 & 2 & + & + & + \\
$3 * *$ & $\mathrm{M}$ & 29 & 1 & + & + & + \\
$4 * *$ & $\mathrm{M}$ & 24 & 1 & - & - & - \\
$5 * * *$ & $\mathrm{M}$ & 27 & 4 & + & - & - \\
$6 * *$ & $\mathrm{~F}$ & 15 & 1 & - & - & - \\
$7 * *$ & $\mathrm{M}$ & 24 & 2 & + & + & -
\end{tabular}

Histology: * Labrea-simile, ** Severe acute hepatitis with spongiocytic cells, *** Coagulative necrosis + polymorphonuclear leukocytes + spongiocytic cells.

data were obtained from all cases. Results were negative for yellow fever, hemorrhagic fevers (West Nile, Rift Valley, Lassa, Marburg, Ebola). Sera were also tested by immunofluorescence and were inoculated into suckling mice and placed on cellular culture (Vero E6 - AP 61) at the Institut Pasteur Bangui to complete the study for the identification of arboviruses, always with negative results.
Approximately 200 similar cases have been observed in the Central African Republic since $1982^{19}$.

Fragments of livers were obtained at necropsy in most of the cases and by needle post-mortem "biopsy". They were fixed in neutral $10 \%$ formalin and embedded in paraffin. Sections were stained with hematoxylin \& eosin and representative sections were additionally stained with the following: 1 . Gomori's reticulum; 2. Masson's trichrome; 3. periodic acid Schiff (PAS), and 4. picrosirius red for collagen. An immunoperoxidase (PAP) technique for the demonstration of Hbsag, Hbcag and Delta antigen was performed on paraffin sections from all the cases, as described elsewhere for the Brazilian cases $^{23}$.

Representative wet-tissue blocks were cut on a freezing microtome and the sections stained with Sudan Black for the demonstration of fat.

\section{RESULTS}

The Brazilian cases were strikingly similar to one another and will be described first. General lobular architecture of the liver was preserved. The presence of swollen and vacuolated liver cells, with a central nucleus and a spongy or morular cy toplasm dominated the picture (Figures 1 and 2). These cells

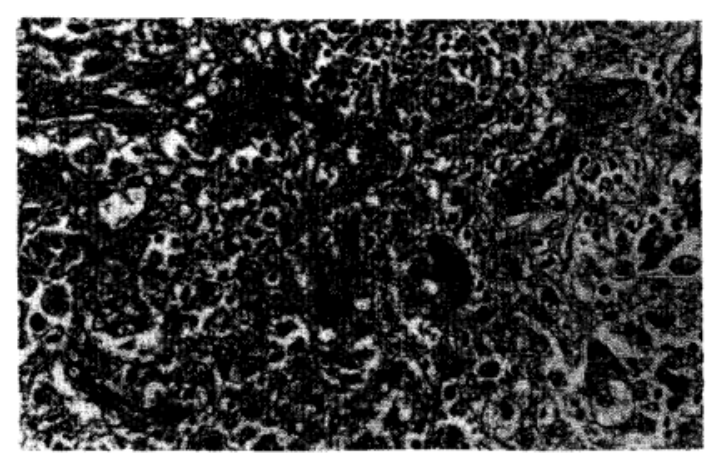

Figure 1 - Labrea hepatitis of seven day duration. There can be seen parenchymal disarray, swollen and vacuolated hepatocytes, focal dropping out oflivercells, abnomal bile duct and mononuclear-cell infiltration. Hematoxylin \& Eosin, $250 X$.

appeared throughout the sections with no preferential distribution within the lobule. The vacuolar transformation could be total or partial and could affect cells having multiple nuclei, cells in pseudoacinar arrangement and cells of various sizes. 
Andrade ZA, Lesbordes JL, Ravisse P, Paraná R, Prata A, Barberino JS, Trepo C. Fulminant hepatitis with microvesicular steatosis (A histologic comparison of cases occurring in Brazil - Labrea hepatitis - and in Central Africa - Bangui hepatitis). Revista da Sociedade Brasileira de Medicina Tropical 25:155-160, jul-set, 1992.

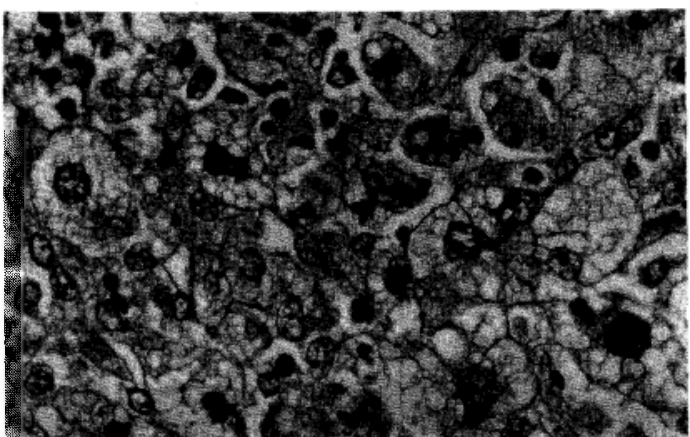

Figure 2 -Higher power view of the previous picture. The liver cells appear enlarged, multivacuolated, with a "spongy" appearance. Hematoxylin \& Eosin, $400 \mathrm{X}$.

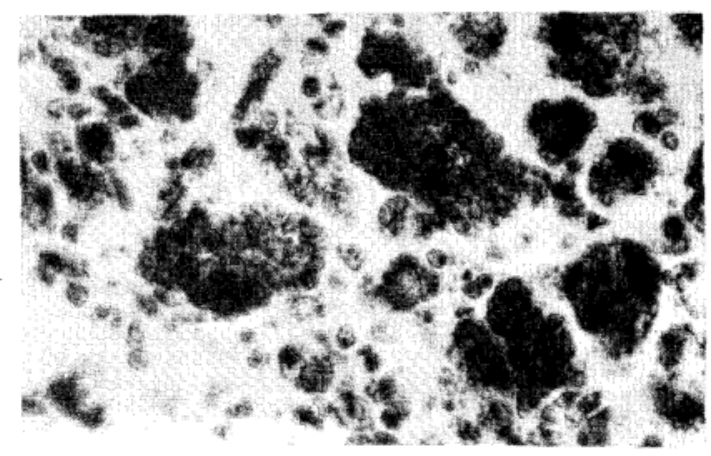

Figure 3 - Labrea hepatitis. The material inside the vacuoles in the hepatocytes stains strongly for fat. Frozen section of formalin fixed material, Sudan Black, $400 \mathrm{X}$.

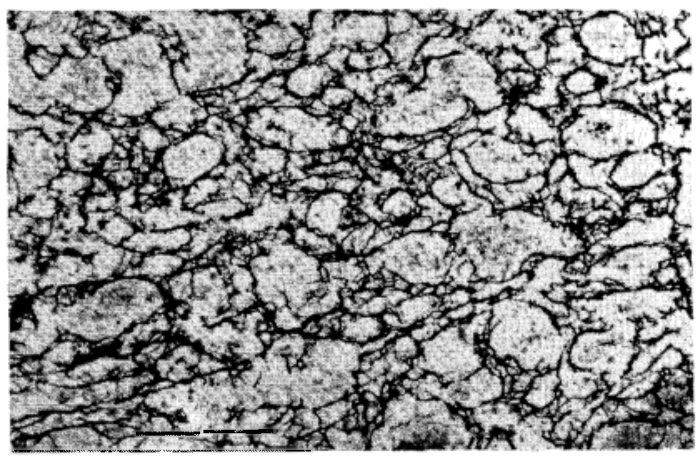

Figure 4 - Labrea hepatitis. The picture is representative of the changes affecting the reticular framework of the liver. There is no massive collapse, but only patchy foci of reticulum condensation. Gomori's reticulum stain, $200 \mathrm{X}$.

Vacuoles stained strongly for fat (Figure 3) Side by side with the vacuolar changes there was lytic necrosis (dropping out) of liver cells as well as diffuse infiltration by mononuclear leukocytes. No massive or submassive necrosis was ever seen, the silver impregnated hepatic reticulum appeared generally preserved, although with microscopic foci of condensation, especially around the central and sublobular veins (Figure 4).

Coagulative necrosis was also present, but not as frequently or disseminately as the vacuolar or lytic changes. Usually the coagulative single-cell necrosis did not form dense, round, hyaline corpuscles, but exhibited a rather smudgy and irregular appearence. As for the inflammatory cells, macrophages and lymphocytes were prominent, polymorphonuclear neutrophils and eosinophils being extremely rare.

Portal spaces showed edema, chronic inflammation and ductular proliferation. These changes became more evident in the cases of more prolonged duration. With time, the accumulation of leukocytes in the portal spaces also increased (Figure 5) and the proliferated bile ducts exhibited atypical hyperplasia. Even in isolated ductal structures, abnormal bile duct epithelium exhibited vacuolate enlarged and hyperchromatic nuclei (Figure 6). Morphological signs of cholestasis, represented by bile thrombi, bile impregnation of ductal and parenchymal cells, were seen in most of the cases, but never represented a prominent change.

Positive staining for Delta antigen was found in 4 cases. The antigen appeared as a dark homogeneous, peroxidade-positive spot in the nuclei of hepatocytes, always scattered and few in numbers, the maximum observed in a $40 \mathrm{x}$ microscopic field being 4 .

The examined Bangui cases could be divided into three groups: the first was represented by two cases which exhibited exactly the same histopathological picture as the cases described above. The second group consisted of one case, that besides having the features of the previous cases, presented hyaline coagulative necrosis as a conspicuous change. In addition, such latter change was accompanied by focal and marked infiltration of polymorphonuclear leukocytes (Figure 7). The spongy hepatocytes appeared mingled with the hyaline necrotic cells and the polymorphonuclear leukocytes. Such a combination of changes had not been observed in the Brazilian cases. The third group was represented by 4 cases which presented the classical features of severe acute viral hepatitis 
Andrade ZA, Lesbordes $J$, Ravisse P, Paraná R, Prata A, Barberino JS, Trepo C. Fulminant hepatitis with microvesicular steatosis (A histologic comparison of cases occurring in Brazil - Labrea hepatitis - and in Central Africa - Bangui hepatitis). Revista da Sociedade Brasileira de Medicina Tropical 25:155-160, jul-set, 1992.

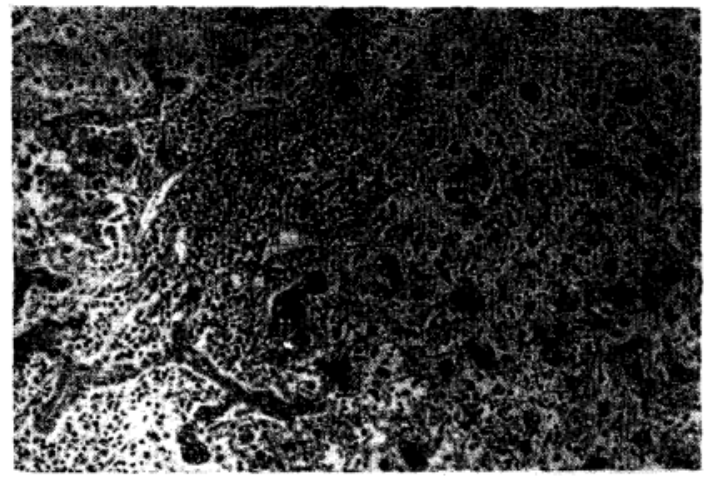

Figure 5- Labrea hepatitis. Abnormal, hyperplastic and degenerated bile ducts in a portal space with dense mononuclear-cell infiltration. The inflammatory cells seem to penetrated and dissociate the limiting parenchymallantina ("spill-over"). Masson trichrome stain, $I 20 X$.

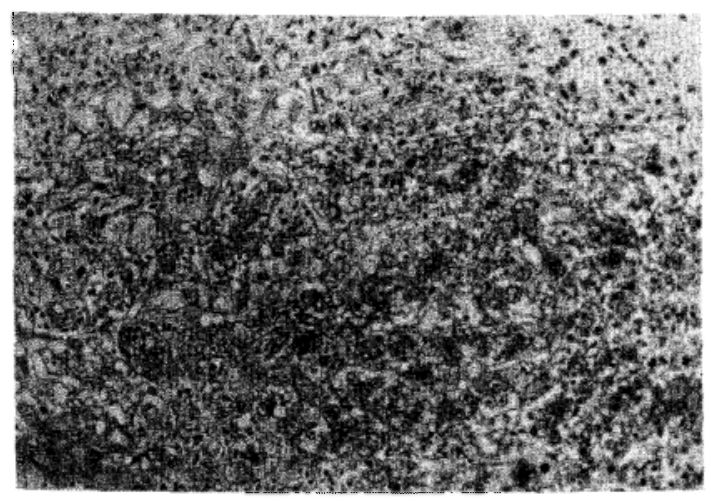

Figure 6 - Bangui hepatitis. Acule hepatitis with prominent vacuolar or "spongiocytic" changes in hepatocytes, plus hyaline single-cell necrosis and inflammation with mononuclear and polymorphonuclearleukocytic infiltration. Hematoxylin \& Eosin, $120 \mathrm{X}$.

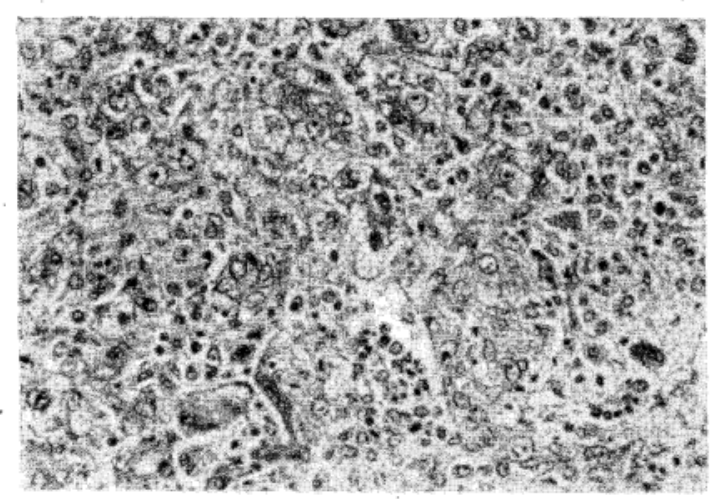

Figure 7 - Bangui hepatitis. Detail showing the hepatocytic fatty changes and mononuclear-cell infiltration. Hematoxylin \& Eosin, $200 \mathrm{X}$. with submassive necrosis and collapse, but having in addition many partially or totally multivacuolated hepatocytes, either scattered or in small clusters (Figure 8). Signs of cholestasis in these last four cases were much more evident than in the Brazilian cases.

\section{DISCUSSION}

The present comparative study reveals that the severe and peculiar form of acute hepatitis occurring in South America and in Central Africa, which shares a similar equatorial ecological background, also presents similar histopathological features. The Brazilian cases studied were apparently more homogeneous than the African ones. This may be related to case selection, which is linked to the matter of conceptual definition. Labrea hepatitis in Brazil has been primarily considered as a clinical entity which occurs in microepidemics, affects children, presents a fulminant course and shows prominent signs of central nervous system involvement ${ }^{3}$. Cases considered as classical acute fulminant viral hepatitis occurring in the same geographic area in adults are separated from Labrea hepatitis and are not usually submitted to histological examination. When unselected cases of fulminat hepatitis from the Amazonian region were considered, a variable histological picture was demonstrated. Dias and Coura ${ }^{11}$ reported on 28 such unselected cases, from which 11 presented the classical histological features of Labrea hepatitis, 5 showed some but not all characteristics of that condition and 5 presented classical acute hepatitis with massive or submassive necrosis. This corresponds to approximately the same situation observed in Central Africa.

Therefore, in both regions a modified form of acute severe hepatitis with the presence of multivacuolated hepatocytes (spongy or morular transformation) serving as hallmarks can be observed.

Diffuse hepatocytic acute fatty changes with cell swelling are a.well known toxic manifestation which may be associated with acute fatty liver of pregnancy ${ }^{6}$, tetracycline therapy ${ }^{16}$ and hycanthone intoxication ${ }^{2}$. It has been considered as a consequence of impairment of low density lipo-protein metabolism in the liver. 
Andrade ZA, Lesbordes $J L$, Ravisse $P$, Paraná $R$, Prata A, Barberino JS, Trepo C. Fulminant hepatitis with microvesicular steatosis (A histologic comparison of cases occurring in Brazil - Labrea hepatitis - and in Central Africa - Bangui hepatitis). Revista da Sociedade Brasileira de Medicina Tropical 25:155-160, jul-set, 1992.

The association with superinfection of hepatitis B virus carriers by the hepatitis Delta virus is strongly suggested by epidemiological, serological and immunohistological findings in both series, which were considered here. Additional unknown etiologic factors, environmental factor(s) present in equatorial forest areas may also play roles. Further studies are necessary to clarify this very important point. Co-infection with other important hepatotropic viruses, such as hepatitis $C$ and $E$ viruses, has not been investigated in the present series. Althought HEV has not so far been reported from the areas studied here, the so-called non-A, non-B hepatitis is not rare in Brazil or Africa ${ }^{5}$.

Finally, preliminary results of transmission of the Bangui strain of HDV to WHV carrier woodchucks suggest that the abnormal proportion of severe hepatitis forms responsible for these equatorial outbreaks may in fact be due to a more cytopathic strain of HDV 2125.

\section{RESUMO}

Um quadro histopatológico similar de hepatite fatal, associado a mudanças adiposas agudas, muito espalhadas em hepatócitos e necrose unicelular, foi visto em casos epidêmicos ocorrendo em duas diferentes áreas equatoriais, com alta prevalência de infecções $H B V e$ $H D V$. Os casos foram previamente considerados como sendo duas entidades diferentes: hepatite de Labrea no Brasil $e$ hepatite de Bangui na República da África Central. Contudo, os achados histopatológicos sugerem que são patogênica e etiologicamente relacionados a infecções $H B V$ e $H D V$, provavelmente modificados por algum fator ainda desconhecido, presente nas zonas de floresta equatorial.

Palavras-chaves: Hepatite de Labrea. Hepatite de Bangui. Infecção delta. Hepatite espongiocítica.

\section{REFERENCES}

1. AndradeZA, Barbosa Jr AA. Hepatite de Lábrea em Salvador, Bahia? (Apresentação de um possível caso). Memórias do Instituto Oswaldo Cruz 78:491496, 1938.

2. Andrade ZA, Santos HA, Borojevic R, Grimaud JA. Lesões hepáticas produzidas por Hycanthone (Etrenol). Revista do Instituto de Medicina Tropical de São Paulo 16:160-170, 1974.

3. Andrade ZA, Santos JB, Prata A, Dourado H.
Histopatologia da hepatite de Lábrea. Revista da Sociedade Brasileira de Medicina Tropical 16:3140, 1983.

4. Bensabath G, Dias LB. Hepatite de Lábrea (Febre Negra de Lábrea) e outras hepatites fulminantes en Sena Madureira, Acre e Boca do Acre, Amazonas, Brasil. Revista do Instituto de Medicina Tropical de São Paulo 25:182-194, 1983.

5. Bradley DW, Krawczynski K, Beach MJ, Purdy MA. Non-A, Non-B Hepatitis: toward the discovery of hepatitis $\mathrm{C}$ and $\mathrm{E}$ viruses. Seminar in Liver Diseases 2:128-146, 1991.

6. Breen KJ, Perkins KW, Mistilis SP, Shearman R. Idiopathic acute fatty liver of pregnancy. Gut 11:822$825,1970$.

7. Buitrago B, Popper H, Hadler SC, Thung SN, Gerber MA, Purcell RH, Maynard JE. Specific histologic features of Santa Marta hepatitis. A severe form of hepatitis Delta infection in Northern South America. Hepatology 6:1285-1291, 1988.

8. Costa EA. Febre Negra no rio Purus, algumas observações acerca de um surto na "Boca do Inferno", Amazonas. Gazeta Médica da Bahia 70:148-175, 1970.

9. De Paola D, Pinheiro AP, Dias LB, Lacerda PRS. "Febre Negra" da Amazônia. Sua possível significação. O Hospital 71:123-131, 1967.

10. De Paola D, Strano AJ, Hopps. Labrea Hepatitis (Black Fever). A problem in geographic pathology. Bulletin of the International Academy of Pathology 9:43-49, 1968.

11. Dias LB, Coura JR. Hepatite de Lábrea. Estudo de revisão em viscerotomias hepáticas dos anos 19341940. Revista do Instituto de Medicina Tropical de São Paulo 27:242-248, 1985.

12. Dias LB, Moraes MAP. Hepatite de Lábrea. Revista do Instituto de Medicina Tropical de São Paulo 15:86-93, 1973.

13. Fonseca JCF, Gayotto LCC, Ferreira LCL, Araujo JR, Alecrim WD, Santos RTH, Simonetti JP, Alves JVF. Labrea Hepatitis - Hepatitis B and Delta antigen expression in liver tissue: report of three autopsy cases. Revista do Instituto de Medicina Tropical de São Paulo 27:224-227, 1985.

14. Gast-Galvis A. Viscerotomia em Colombia. Resultado del examen histo-patologico de 20.000 muestras de higado humano. Revista Medica (Bogota) 553:1-34, 1975.

15. Hadler SC, Monzon M, Ponzetto A, Anzola E, Rivero D, Mondolfi A, Bracho A, Francis DP, Gerber MA, Thung S, Gerin J, Maynard JS, Popper $H$, Purcell RH. Delta virus infection and severe hepatitis. An epidemic in Yucpa Indians of Venezuela. Annals of Internal Medicine 100:339$344,1984$. 
Andrade ZA, Lesbordes $J$, Ravisse P, Paraná R, Prata A, Barberino JS, Trepo C. Fulminant hepatitis with microvesicular steatosis (A histologic comparison of cases occurring in Brazil - Labrea hepatitis - and in Central Africa - Bangui hepatitis). Revista da Sociedade Brasileira de Medicina Tropical 25:155-160, jul-set, 1992.

16. Hansen CH, Pearson LH, Schenker S, Combes B. Impaired secretion of triglycerides by the liver: a cause oftetracycline-induced fatty liver. Proceedings of the Society of Experimental Biology and Medicine 128:143-146, 1968.

17. Kanel GC, Govindarajan S, Peters RJ. Chronic Delta infection and liver biopsy changes in chronic active hepatitis B. Annals of Internal Medicine 101:51-54, 1984.

18. Lefkowicth JH, Goldstein H, Yatto R, Gerber HA. Cytopathic liver injury in acute Delta virus hepatitis. Gastroenterology 92:1262-1266, 1987.

19. Lesbordes JL, Ravisse P, Georges AJ, Chevalier P, Pichoud C, Vitvitski L, Trepo C. Studies on the role of HDV in an outbreak of fulminat hepatitis in Bangui (Central African Republic). In: Alan R (ed) The Hepatitis Delta and its Infections, Liss Inc, New York p.451-459, 1987.

20. Lesbordes JL, Ravisse P, Georges AJ, Beuzit Y, Ave P, Enanra D, Meunier MY, Georges MC, Gonzalez JP, Chevalier P, Pichoud C, Trepo C. Le rôle du virus Delta dans les hepatites fulminantes en Afrique Centrale. Annales de Médecine Interne 138:199-201, 1987.

21. Paraná R, Lesbordes JL, Gerad F, Jaquet C, Pichoud C, Vitvitski L, Chomel B, Trepo C. Demonstration of the experimental transmission to woodchucks of the hepatitis delta virus associated with a form of spongiocytic hepatitis. American Association for the Study of Liver Diseases (Nov, 7-8, Chicago, USA), 1988.

22. Pelletier L, Lecante A, Destombres P, Serie CH. La fièvre noire amazoniènne en Guyane Française. Archives de l'Institut Pasteur de la Guyane Française et de l'ININI 21:78-82, 1968.

23. Popper H, Buitrago B, Hadler SC, Thung SN, Gerber MA, Purcell RH, Maynard JE. Pathology of hepatitis Delta infection in the Amazon basin. In: Alan R (ed) The Hepatitis Delta Virus and its Infections. Liss Inc, New York p.121-128, 1987.

24. Popper H, Thung SN, Gerber M, Hadler SC, Monzon M, Ponzetto A, Anzola E, Rivera D, Mondolfi A, Bracho A, Francis DP, Gerin JL, Maynard JE, Purcell RH. Histologic studies of severe Delta agent infection in Venezuela Indians. Hepatology 3:906-912, 1983.

25. Trepo C, Parana R, Gerard F, Jacquet C, Vitvitski L, Chomel B, Lesbordes JL. Successful transmission to woodchucks of a highly cytopathic hepatitis delta virus (HDV) strain responsible for fulminant hepatitis in the Central African Republic. Hepatology 8:1389, 1988.

26. Villanueva A, Frazer $P$, Garcia R, Ospino R, Ariza $P$, O'Brien T. Fulminant hepatitis in the Sierra Nevada: a superinfection of Delta virus on hepatitis $B$ virus. In: Alan R (ed) Viral Hepatitis and Liver Diseases, Liss Inc, New York p.415-420, 1988. 